\title{
EFEKTIVITAS MODEL PEMBELAJARAN TPR (TOTAL PHYSICAL RESPONSE) DALAM PENGAJARAN BAHASA INGGRIS
}

\author{
Azhari Ikhwati, Erna Megawati \\ Program Studi Pendidikan Bahasa Indonesia \\ Universitas Indraprasta PGRI \\ azhariikhwati@gmail.com,megawatie45@yahoo.com
}

\begin{abstract}
Abstrak.
Tujuan penelitian ini adalah untuk mengetahui seberapa efektif penggunaan model pembelajaran TPR (Total Pysical Response) dalam pengajaran kosa kata bahasa Inggris.. Subyek di sini adalah peserta didik kelompok belajar yang ada di desa Sukamulya, kecamatan Sukamakmur, Bogor. Penelitian ini dirancang dengan menggunakan metode eksperimen dengan bentuk desain preexperimental design dengan jenis one group pretest-posttest design. Adapun pada jenis penelitian ini akan dilakuan pretest dan posttest terhadap kemampuan peserta didik. Pretest dilakukan sebelum diberikannya treatment atau perlakuan. Selanjutnya posttest diberikan setelah treatment atau perlakuan dilakukan. Dengan diberikannya pretest dan posttest, hasil dari treatment akan lebih akurat, karena dapat membandingkan dengan keadaan sebelum diberikan perlakuan. Adapun hasil penelitian ini berdasarkan hasil penelitian yang dilakukan dapat disimpulkan bahwa terdapat perbedaan yang signifikan antara kelompok belajar yang mendapat model pembelajaran TPR dengan kelompok belajar yang tidak mendapatkan model pembelajaran TPR. Hal tersebut menunjukkan bahwa model pembelajaran TPR efektif digunakan dalam pengajaran kosa kata bahasa Inggris.Secara umum dapat diketahui skor pretest ketika kelompok belajar tidak menggunakan model pembelajaran TPR nilai terendahnya adalah 0 dan tertinggi 9, sedangkan skor posttest ketika kelompok belajar menggunakan model pembelajaran TPR adalah 2 dan tertinggi 13. Perhitungan SPSS 16 kolom Asym.Sig.(2-tailed)/asymptotic significance untuk uji dua sisi menunjukkan 0,000 atau probabilitas di bawah $0,05(0,000<0,05)$, maka $\mathrm{H}_{\mathrm{o}}$ ditolak atau skor kelompok belajar yang tidak mendapat model pembelajaran TPR benar-benar berbeda dengan skor kelompok belajar yang mendapat model pembelajaran TPR
\end{abstract}

Kata Kunci: Model Pembelajaran TPR, Pengajaran Bahasa Inggris, Buta Aksara

\begin{abstract}
:
The purpose of this research is to discover the effectivity of the usage of TPR(Total Pysical Response) learning model in teaching English course. The subjects of this research were all the learners of learning group in Sukamulya village, Sukamakmur, Bogor. In this research, the researcher used preexperimental design which is one group pretest-posttest design. The researcher had taken pretest and posttest to measure the learners' ability. Pretest was taken before the treatment while posttest was done after the treatment. In this way, it could show the accuracy of the method. Based on the research, it could be concluded that the result of study using TPR was significantly higher than using the conventional was. This result could be seen from the lowest and highest score achieved in conventional way were 0 and 9 while the result from $T P R$ showed that the lowest and highest score were 2 and 13. It was supported the calculation using SPSS 16 that showed in the column of Asym.Sig.(2-tailed)/asymptotic significance for two sides pointing 0,000 or probability below $0,05(0,000<0,05)$, in this case $H_{o}$ was rejected or it could been said if the result of the learning group using conventional way was siginificantly different from the result using TPR.
\end{abstract}

Key words: TPR method of learning, English Teaching, Illiterate. 


\section{PENDAHULUAN}

Pendidikan adalah hal terpenting dalam kehidupan manusia. Tanpa pendidikan, manusia akan hidup dalam ketidaktahuan. Secara hakiki manusia dibedakan dengan makhluk lainnya karena manusia dikarunia akal dan pikiran untuk bisa menghadapi persoalan-persoalan hidupnya. Demikian pentingnya persoalan pendidikan bagi hidup manusia sehingga dapat dibayangkan jika hidup tanpa adanya pendidikan.

Melalui pendidikan, manusia diperkenalkan kepada nilai-nilai yang dibutuhkan di dalam kehidupannya dalam rangka pemenuhan segala kebutuhan hidupnya. Salah satu kebutuhan paling mendasar yang diperlukan oleh manusia adalah kebutuhan akan komunikasi. Melalui komunikasi maka seseorang dapat menyampaikan pesan atau keinginannya kepada orang lain. Sebaliknya, melalui komunikasi maka seseorang juga dapat menangkap berbagai pesan yang disampaikan pihak lain yang kemungkinan sangat berguna bagi kehidupannya.

Manusia berkomunikasi melalui bahasa. Pada era globalisasi dimana batas antarnegara tidak lagi menjadi masalah, maka seseorang dari Negara lain dapat masuk ke Indonesia dengan mudahnya. Hal tersebut tentu membawa dampak positif serta negatif. Dampak negatif dapat muncul seiring masuknya bangsa dan budaya asing ke Indonesia. Hal taktis yang bisa dipersiapkan dalam rangka menghadapi yang demikian adalah melalui persiapan bahasa sehingga memungkinkan terjadinya pemahaman yang tepat dan benar terhadap bangsa dan budaya asing.

Suatu masyarakat akan mengalami kemerosotan jika mereka gagal memahami makna komunikasi suatu bahasa yang berlaku secara internasional. Komunikasi antar individu maupun antarkelompok dengan berbagai latar belakang kebudayaan akan dapat berlangsung dengan efektif bila semua interlocutor menguasai bahasa yang dikuasai bersama, dalam konteks ini bahasa Inggris menjadi bahasa internasional. Kondisi ini menjadikan bahasa Inggris menjadi bahasa yang paling penting untuk dikuasai, temasuk oleh bangsa Indonesia, baik untuk tujuan penyerapan dan pengembangan ilmu, teknologi dan seni budaya serta untuk membina hubungan dengan bangsabangsa lain di dunia (Murdibjono, 1996: 1). Dampak logis yang tercipta adalah munculnya kebutuhan akan pentingnya bahasa Inggris bagi setiap individu yang ingin terlibat dalam pergaulan antarbangsa. Tanpa penguasaan bahasa Inggris, seseorang akan tersingkir dari setiap forum antarbangsa. Harmer (1998: 13) mengatakan "By the end of twentieh century English was already well on its way to becoming a genuine lingua franca, that is a language used widely for communication between people who do not share the same first (or even second) language." Pada akhir abad ke dua puluh, bahasa Inggris telah menjadi lingua franca yaitu bahasa yang digunakan secara luas untuk berkomunikasi di antara orang-orang yang tidak mempunyai bahasa ibu yang sama (bahkan bahasa kedua yang sama).

Menyadari betapa pentingnya kemahiran berbahasa Inggris bagi setiap individu, termasuk bagi para peserta didik Indonesia sebagai calon pemimpin bangsa di masa yang akan datang, pembelajaran bahasa Inggris bagi anak Indonesia adalah tantangan yang harus direspon dengan upaya-upaya yang serius mengingat bahwa setiap pembelajaran bahasa merupakan pekerjaan yang rumit karena melibatkan banyak faktor, yang oleh Harmer (1991: 
3-8) dibagi menjadi: motivasi, kondisi dan suasana tempat belajar, metode pengajaran, dan kompetensi pengajar.

Berbagai cara dilakukan oleh seorang pendidik supaa peserta didik dapat memahami bahasa Inggris secara mudah dan efisien. Metode yang tepat sangat diperlukan dalam penyampaian pembelajaran bahasa Inggris dikarenakan bahasa Inggris masih merupakan bahasa asing di Indonesia. Hal tersebut menjadi lebih penting lagi dikarenakan masih banyak anak negeri yang buta aksara dan hitung.

Berdasarkan latar belakang tersebut di atas dan menilai pentingnya suatu pemerataan pengajaran semua segmen masyarakat, maka dilakukan penelitian dengan judul Efektivitas Model Pembelajaran TPR (Total Physical Response) dalam Pengajaran Kosa kata Bahasa Inggris pada Kelompok Belajar Peserta didik dalam usaha Pemberatasan Buta Aksara di Kampung Mulyasari, Desa Sukamulya, Kecamatan Sukamakmur, Bogor. Hasil penelitian ini diharapkan dapat memberikan kontribusi dalam mensolusikan kendala yang dihadapi praktisi pendidikandalam pengajaran bahasa.

\section{Hakikat Pembelajaran}

Kata Pembelajaran yang berkorelasi dengan kata "mengajar" berasal dari kata dasar "ajar" yang berarti petunjuk yang diberikan kepada orang supaya diketahui (diturut) (KKBI) kemudian dari kata dasar ditambah dengan awalan "pe" dan akhiran "an" menjadi "pembelajaran", menjadi proses, perbuatan, cara mengajar atau mengajarkan sehingga anak didik belajar. (KBBI)

Duffy dan Roehler (1989) dalam Badarudin (2012) mengungkapkan bahwa pembelajaran adalah suatu usaha yang sengaja melibatkan dan meng- gunakan pengetahuan profesional yang dimiliki guru untuk mencapai tujuan kurikulum.

Gagne dan Briggs (1979:3) dalam Badarudin (2012) mengartikan instruction atau pembelajaran ini adalah suatu sistem yang bertujuan untuk membantu proses belajar siswa, yang berisi serangkaian peristiwa yang dirancang, disusun sedemikian rupa untuk memengaruhi dan mendukung terjadinya proses belajar siswa yang bersifat internal.

Dengan demikian menjadi jelas bahwa pembelajaran merupakan suatu usaha yang sengaja yang dilakukan secara sistemik dan berisi konsep yang akan digunakan untuk membantu proses belajar siswa secara internal yang terhubung dengan pencapaian tujuan kurikulum.

\section{Model Pembelajaran TPR}

Total Physical Respons (TPR) merupakan metode pengajaran bahasa yang dikembangkan pada tahun 1970-an oleh Asher, seorang profesor psikologi di Universitas San Jose California berdasarkan hasil pengamatan terhadap cara yang digunakan bayi untuk memperoleh bahasa ibunya. Anak memberi respon fisik terhadap instruksi orang-tua atau orang lain di sekitar mereka. Sebagai contoh, ketika seorang ayah berkata: "Listen to me" atau "sit down" maka si anak akan merespon secara fisik. interaksi seperti ini berlangsung selama beberapa bulan hingga si anak mampu memberi respon verbal. Pada fase ini si anak sebenarnya sedang berupaya menguasai elemenelemen bahasa yang didengarnya. Setelah penguasaannya memadai, si anak akan memberi respon verbal secara spontan.

Seiring dengan hal tersebut, Richards and Rogers (1986: 87) mendefinisikan TPR sebagai "a 
language teaching method built around coordination of speech and action; it attempts to teach language through physical (motor) activity". TPR adalah sejenis metode pengajaran bahasa yang menitik beratkan pembelajaran pada koordinasi ucapan dan tindakan dalam rangka mengajarkan bahasa melalui aktivitas fisik (motorik).

Dalam proses pembelajaran, peserta didik tidak perlu berbicara. Tugas utama mereka adalah melaksanakan intruksi verbal pengajar yang dilakukan secara berulang-ulang hingga lancar. Hal tersebut akan memudahkan peserta didik mengingat kata yang diajarkan. Pemberian perintah, model, dukungan, dan hubungan yang akrab yang berkelanjutan dari pengajar secara psikologis akan membuat peserta didik dapat belajar tanpa tekanan.

Prosedur pelaksanaan TPR diawali dengan pemberikan perintah berbentuk sebuah kata (seperti: "Open!" atau close!") kemudian meningkat menjadi sebuah frasa (seperti: 'open the door'). Peserta didik diminta untuk melaksanakan komando tersebut. Kegiatan tersebut dilakukan berulangulang hingga peserta didik bisa melaksanakan intruksi dengan lancar.

Keterbatasan TPR:

a. Akan sulit diterapkan pada peserta didik yang berkarakter pemalu.

b. Sulit untu melakonkan kata-kata abstrak.

c. Kurang mengembangkan keterampilan berbicara.

d. Peserta didik menjadi tidak kreatif.

e. Membutuhkan banyak alat peraga.

f. Sulit untuk digunakan dalam pengajaran bahasa pada tataran struktur dan makna.

\section{Pengertian bahasa Inggris}

Bahasa Inggris berfungsi sebagai alat untuk berkomunikasi dalam rangka mengakses informasi, dana dalam konteks sehari-hari, sebagai alat untuk membina hubungan interpersonal, bertukar informasi serta menikmati estetika bahasa dalam budaya Inggris.

Mata pelajaran bahasa Inggris memiliki tujuan sebagai berikut:

1. Mengembangkan kemampuan berkomunikasi dalam bahasa tersebut, dalam bentuk lisan dan tulis. Kemampuan berkomunikasi meliputi mendengarkan (listening), berbicara (speaking), membaca (reading), dan menulis (writing).

2. Menumbuhkan kesadaran tentang hakikat dan pentingnya bahasa Inggris sebagai salah satu bahasa asing untuk menjadi alat utama belajar.

3. Mengembangkan pemahaman tentang saling keterkaitan antar bahasa dan budaya serta memperluas cakrawala budaya. Demikian siswa memiliki wawasan lintas budaya dan melibatkan diri dalam keragaman budaya.

\section{Hakikat Kosakata (Vocabulary)}

Kosakata (Vocabulary) adalah sejumlah kata dalam bahasa yang digunakan untuk mengekspresikan pikiran. Kosakata yang merupakan kumpulan kata dari suatu bahasa yang dikuasai dan digunakan dalam berkomunikasi-baik secara lisan maupun tulisan, merupakan salah satu elemen bahasa yang harus dikuasai yang memungkinkan seseorang memahami pesan yang disampaikan kepadanya maupun menyampaikan pesan kepada lawan bicaranya. Astipuri (2011), Katakata yang dimengerti oleh orang tersebut atau semua kata-kata yang kemungkinan akan digunakannya untuk menyusun kalimat baru sehingga proses penambahan kosa kata menjadi hal yang penting dalam pembelaaran maupun pengembangan bahasa. 
Macam-macam

kosakata

(Vocabulary) di antaranya adalah:

1. Vocabulary produktif (sering digunakan)

Jenis kosakata ini dikatakan produktif karena frekuensi penggunaannya yang sangat tinggi sehingga kata-kata ini menjadi tidak asing dan biasanya mudah dipahami. Contoh: school, air, water, dll.

2. Vocabulary tidak produktif (jarang digunakan)

Jenis kosakata yang tidak lazim digunakan dalam pembuatan kalimat atau percakapan sehingga cenderung sukar dipahami.

Contoh: turbulence, surgery, pilgirm, dll

\section{METODE PENELITIAN}

Penelitian ini dilaksanakan selama 5 (lima) bulan terhitung sejak bulan April sampai Agustus 2017. Berdasarkan tujuan penelitian yaitu meningkatkan penguasaan kosakata bahasa Inggris peserta didik kelompok belajar dengan motode Total Physical Response, maka peneliti menggunakan metode penelitian eksperimen. Beberapa bentuk desain eksperimen yang dapat digunakan dalam penelitian yaitu preexperimental design, true experimental design, factorial design, dan quasi experimental design Sugiyono (2012: 110).

Dalam penelitian ini, peneliti menggunakan metode eksperimen dengan bentuk desain preexperimental design dengan jenis one group pretestposttest design. Adapun pada jenis penelitian ini akan dilakuan pretest dan posttest terhadap kemampuan peserta didik. Pretest dilakukan sebelum diberikannya treatment atau perlakuan. Selajutnya posttest diberikan setelah treatment atau perlakuan dilakukan. Dengan diberikannya pretest dan posttest hasil dari perlakuan dapat diketahui lebih akurat, karena dapat membandingkan dengan keadaan sebelum diberikan perlakuan.

Variabel adalah segala sesuatu yang akan menjadi objek pengamatan dalampenelitian. Variabel penelitian adalah suatu atribut atau sifat atau nilai dari orang, obyek atau kegiatan yang mempunyai variasi tertentu yang di tetapkan oleh peneliti untuk dipelajari dan kemudian di tarik simpulannya. Variable terikat yang diukur adalah penguasaan kosakata bahasa Inggris dalam ruang lingkup kata benda yang ada disekitar lingkungan peserta didik. Variable terikat tersebut dikontrol dengan menggunakan pre-test dan posttest dengan menggunakan metode Total Physical Response.

Populasi dalam penelitian ini adalah seluruh peserta didik kelompok belajar di Kampung Mulyasari yang berjumlah 30 anak. Peneliti memilih subjek peserta didik kelompok belajar usia $6-12$ tahun berjumlah 16 orang yang memiliki kemampuan bahasa Inggris yang sama yang dilihat berdasarkan hasil tes awal. Dengan diberikannya pre-test mengenai kemampuan kosakata bahasa Inggris dalam ruang lingkup kata benda yang ada disekitar lingkungan peserta didik sebelum perlakuan dari metode Total Physical Respponse dan dengan diberikannya posttest setalah peserta didik mendapat perlakuan Total Physical Response maka akan dapat dilihat terjadinya perubahan skor posttest dibandingkan dengan skor pre-test sebelumnya.

Teknik untuk mengumpulkan data dalam penelitian ini adalah tes. Suharsimi Arikunto (2005:100) mengatakan tes adalah pengumpulan kumpulan beberapa pertanyaan atau alat lain yang digunakan untuk mengukur keterampilan, pengetahuan IQ, 
kemampuan atau bakat yang dimiliki oleh individu atau kelompok. Tes yang diberikan kepada anak, dalam bentuk tes lisan dan perbuatan. Anak diminta menyebutkan kosakata kata benda dalam bahasa Inggris dan menunjukkan benda yang diucapkan dengan bahasa Inggris.

Alat pengumpul data yang digunakan adalah instrumen penelitian. Dalam penelitian ini peneliti langsung mengamati dan mencatat kemampuan anak mengartikan kosakata, melafalkan kata.Untuk menilai kemampuan anak dalam penguasaan kosakata digunakan kriteria penilaian yang dikemukakan Arikunto (1993: 29) sebagai berikut:

1. Skor 1 (satu) bila jawaban peserta didik benar

2. Skor 0 (nol) bila jawaban peserta didik salah

Instrumen yang akan diberikan kepada anak berupa seperangkat tes yang disusun dalam bentuk format indikator yang berisi kosakata bahasa Inggris meliputi kata benda yang ada disekitar lingkungan peserta didik dan kata kerja.

Untuk menentukkan kelayakan instrument, dilakukan uji validitas dan reabilitas terhadap instrument. Uji coba instrumen dilaksanakan dengan tujuan untuk mengetahui tingkat validitas dan reliabilitas instrumen penelitian. Instrumen yang valid berarti "instrumen tersebut dapat digunakan untuk mengukur apa yang seharusnya diukur." (Sugiyono, 2006:173). Instrumen yang reliabel berarti "instrumen yang bila digunakan beberapa kali untuk mengukur objek yang sama, akan mendatangkan data yang sama." (Sugiyono, 2006: 173). Penggunaan instrumen yang valid dan reliabel dalam pengumpulan data, diharapkan akan diperoleh data yang dapat dipercaya kebenarannya.

Instrumen yang digunakan diuji validitasnya dengan menggunakan pendapat dari ahli (judgement experts).
Para ahli diminta pendapatnya tentang instrumen yang telah disusun. Para ahli akan memberi keputusan : instrumen dapat digunakan tanpa perbaikan, ada perbaikan, dan mungkin diubah total. Para ahli yang diminta pendapatnya yaitu dua orang dosen Bahasa Inggris, dan satu orang relawan pengajar kelompok belajar yang memegang subjek penelitian.

Instrumen yang telah disusun harus diujicobakan untuk mengetahui data tersebut sudah reliabel atau belum. Adapun subjek ujicoba instrumen ini tentunya harus memiliki karakteristik sama atau mendekati karakteristik subjek yang sebenarnya. Dalam hal ini subjek tersebut adalah peserta didik kelompok belajar yang memiliki kemampuan kosakata bahasa Inggris yang rendah.

Instrumen yang digunakan diuji reliabilitasnya dengan menggunakan test - retest. Test - retest dilakukan dengan cara mencobakan instrumen beberapa kali kepada subjek penelitian. Dalam hal ini, instrumen yang digunakan sama, subjek yang sama, tetapi waktunya berbeda. Reliabilitas diukur dari koefisien korelasi antara percobaan pertama dan berikutnya. "Bila koefisien korelasi positif dan signifikan maka instrumen tersebut sudah dinyatakan reliabel.'(Sugiyono, 2006: 184). Perhitungan koefisien korelasi antara percobaan pertama dan berikutnya yaitu dengan menggunakan rumus korelasi product moment angka kasar.

$$
\mathrm{r}_{\mathrm{xy}}=\frac{\mathrm{N} \cdot \Sigma \mathrm{XY}-(\Sigma \mathrm{X})(\Sigma \mathrm{Y})}{\sqrt{\left(\mathrm{N} \cdot \Sigma \mathrm{X}^{2}\right)-(\Sigma \mathrm{X})^{2} \cdot\left(\mathrm{N} \cdot \Sigma \mathrm{Y}^{2}\right)-(\Sigma \mathrm{Y})^{2}}}
$$

Keterangan :

rxy $=$ Koefisien korelasi $X$ dan $Y$

$X=$ Nilai percobaan awal

$\mathrm{Y}=$ Nilai percobaan akhir

$\mathrm{N}=$ Jumlah Subjek 
Setelah perhitungan relibialitas diketahui koefisien korelasinya $\mathbf{0 , 9 2}$. Menurut Suharsono kriteria koefisiensi korelasi yang mendekati angka $\mathbf{1}$ mempunyai korelasi yang tinggi. Dengan demikian instrumen tersebut mempunyai korelasi sangat tinggi dan dapat dikatakan reliabel sehingga dapat digunakan dalam penelitian.

Untuk mengolah data hasil penelitian, teknik analisis yang digunakan adalah statistic non parametrik, karena subjek penelitiannya kecil serta distribusi dan variasi populasinya tidak memerlukan uji normalitas. Sidney Siegel (1992:145) menyatakan bahwa statistik non parametrik tidak menguji parameter populasi tetapi menguji distribusi. Statistik non parametrik tidak menuntut banyak asumsi bahwa data yang dianalisis tidak harus berdistribusi normal dan digunakan untuk menganalisis data nominal, ordinal. Uji statistika yang digunakan adalah Uji Mann Whitney (uji U) dengan rumusan menurut Moh. Nazir (2005: 205) adalah:

$$
\begin{aligned}
& U_{1}=n_{1} \cdot n_{2}+\frac{n_{2}\left(n_{2}+1\right)}{2}-\sum R_{2} \\
& U_{2}=n_{1} \cdot n_{2}+\frac{n_{1}\left(n_{1}+1\right)}{2}-\sum R_{1}
\end{aligned}
$$

Keterangan :

U1/U2 = Koefisien U tes.

$\mathrm{R} 1=$ Rangking/peringkat kelompok pretes.

$\mathrm{R} 2$ = Rangking/peringkat kelompok postes.

$\mathrm{n} 1=$ Jumlah kelompok pretes.

$\mathrm{n} 2=$ Jumlah kelompok postes.

Dengan kriteria pengujian penilaian ini adalah:

Ha diterima jika $\mathrm{U}$ hitung > U tabel pada taraf signifikan $95 \%$ atau _= 0,05 .

H0 diterima jika $\mathrm{U}$ hitung < $\mathrm{U}$ tabel pada taraf signifikan $95 \%$ atau _ = 0,05 .

\section{HASIL DAN PEMBAHASAN}

Uji statistika yang digunakan adalah Uji Mann Whitney (uji U) menurut Riadi (2016:220), "Mann Whitney $U$ test digunakan untuk membandingkan dua mean populasi independen yang berasal dari populasi yang homogen dan juga dapat digunakan untuk menguji kesamaan dua mean populasi”.

Tabel 1. Data Sampel

\begin{tabular}{llcccc}
\hline NO & SKOR & KELOMPOK & NO & SKOR & KELOMPOK \\
\hline 1 & 2 & KONVEN & 17 & 7 & TPR \\
\hline 2 & 1 & KONVEN & 18 & 3 & TPR \\
\hline 3 & 0 & KONVEN & 19 & 4 & TPR \\
\hline 4 & 1 & KONVEN & 20 & 6 & TPR \\
\hline 5 & 1 & KONVEN & 21 & 5 & TPR \\
\hline 6 & 2 & KONVEN & 22 & 4 & TPR \\
\hline 7 & 0 & KONVEN & 23 & 3 & TPR \\
\hline 8 & 9 & KONVEN & 24 & 13 & TPR \\
\hline 9 & 2 & KONVEN & 25 & 8 & TPR \\
\hline 10 & 6 & KONVEN & 26 & 9 & TPR \\
\hline 11 & 1 & KONVEN & 27 & 5 & TPR
\end{tabular}




\begin{tabular}{llllll}
\hline 12 & 3 & KONVEN & 28 & 8 & TPR \\
\hline 13 & 3 & KONVEN & 29 & 6 & TPR \\
\hline 14 & 0 & KONVEN & 30 & 7 & TPR \\
\hline 15 & 2 & KONVEN & 31 & 6 & TPR \\
\hline 16 & 1 & KONVEN & 32 & 5 & TPR \\
\hline
\end{tabular}

Tabel 2. Output Mann-Whitney Test

Ranks

\begin{tabular}{llllr}
\hline & EKSPERIMEN & $\mathrm{N}$ & Mean Rank & Sum of Ranks \\
\hline SKOR & 1 & 16 & 10.06 & 161.00 \\
\cline { 2 - 5 } & 2 & 16 & 22.94 & 367.00 \\
\cline { 2 - 5 } & Total & 32 & & \\
\hline
\end{tabular}

\begin{tabular}{lr}
\multicolumn{2}{c}{ Test Statistics $^{\boldsymbol{b}}$} \\
\hline Mann-Whitney $U$ & \multicolumn{1}{c}{ SKOR } \\
\hline Wilcoxon $W$ & 25.000 \\
\hline$Z$ & 161.000 \\
\hline Asymp. Sig. (2-tailed) & -3.904 \\
\hline Exact Sig. [2*(1-tailed Sig.)] & .000 \\
\hline
\end{tabular}
a. Not corrected for ties.
b. Grouping Variable: EKSPERIMEN

Data di atas terdiri atas dua sampel yang bebas satu dengan yang lain, yaitu kelompok anak dengan model pembelajaran konvensional dan kelompok anak yang menjalani model pembelajaran TPR. Disini data hanya sedikit dan dianggap tidak diketahui distribusi datanya (berdistribusi bebas), maka digunakan uji non parametrik dengan dua sampel yang independen.

Analisis output Mann-Withney Test dengan hipotesis sebagai berikut.

1. Ha diterima jika $U$ hitung $>U$ tabel pada taraf signifikan $95 \%$ atau $\geq 0,05$.

2. $\mathrm{H}_{\mathrm{o}}$ diterima jika $\mathrm{U}$ hitung $<\mathrm{U}$ tabel pada taraf signifikan $95 \%$ atau $\leq 0,05$.

$\mathrm{H}_{\mathrm{o}}$ kedua populasi dinilai identik yaitu data pada kedua skor kelompok belajar tidak berbeda secara signifikan, sedangkan $\mathrm{H}_{\mathrm{a}}$ kedua skor kelompok belajar tidak identik (berbeda secara signifikan).

Berdasarkan output SPSS 16 di atas terlihat bahwa pada kolom Asym.Sig.(2-tailed)/asymptotic

significance untuk uji dua sisi adalah 0,000 atau probabilitas di bawah 0,05 $(0,000<0,05)$, maka $H_{o}$ ditolak atau skor kelompok belajar yang tidak mendapat model pembelajaran TPR benar-benar berbeda dengan skor kelompok belajar yang mendapat model pembelajaran TPR.

\section{SIMPULAN}

Berdasarkan hasil penelitian yang dilakukan dapat disimpulkan bahwa terdapat perbedaan yang signifikan antara kelompok belajar yang mendapat model pembelajaran TPR dengan 
kelompok belajar yang tidak mendapatkan model pembelajaran TPR. Hal tersebut menunjukkan bahwa model pembelajaran TPR efektif digunakan dalam pengajaran kosa kata bahasa Inggris.

Secara umum dapat diketahui skor pretest ketika kelompok belajar tidak menggunakan model pembelajaran TPR nilai terendahnya adalah 0 dan tertinggi 9, sedangkan skor posttest ketika kelompok belajar menggunakan model pembelajaran TPR adalah 2 dan tertinggi 13.

Berdasarkan hasil penelitian di atas, peneliti menyarankan agar pengajar mata pelajaran bahasa Inggris khususnya pada tingkat pendidikan dasar hendaknya menggunakan model pembelajran TPR sebagai alternatif sebagai pembelajaran di kelas.

\section{DAFTAR PUSTAKA}

Arikunto, S. (2006). Prosedur penelitian. Jakarta: PT. Adi Mahasatya

Duffy dan Roehler. (1989). Improving classroom reading instruction. New York: Radom House.
Harmer, J. (1991). The practice of English language teaching $1^{\text {st }}$ edition. Pearson Longman: London

(1998). The practice of English language teaching $4^{\text {th }}$ edition. Pearson Longman: London

Murdibjono. (1996). Bahasa inggris studi dan pengajaran. Malang

Nasir, M. (1983). Metodologi penelitian. Ghalia Indonesia

Richards dan Rodgers. (1986). The approaches and methods in language teaching. Cambridge: CUP.

Sugiyono. (2012). Metode penelitian kuantitatif, kualitatif dan R\&D. Bandung: Alfabeta

Winataputra, S. (2008). Pengertian pembelajaran. UPI

Internet

Astipuri, R. (September 19, 2011). Efektifitas brain gym dalam meningkatkan vocabulary pada anak.

http://etd.eprints.ums.ac.id/9306 /1/F100060070 